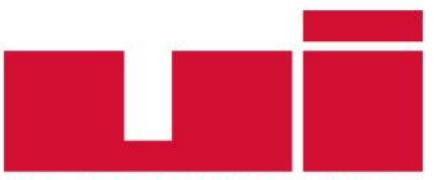

ULUSLARARASIILIȘKiLER

Akademik Dergi

Yayın ilkeleri, izinler ve abonelik hakkında ayrıntılı bilgi:

E-mail: bilgi@uidergisi.com.tr

Web: www.uidergisi.com.tr

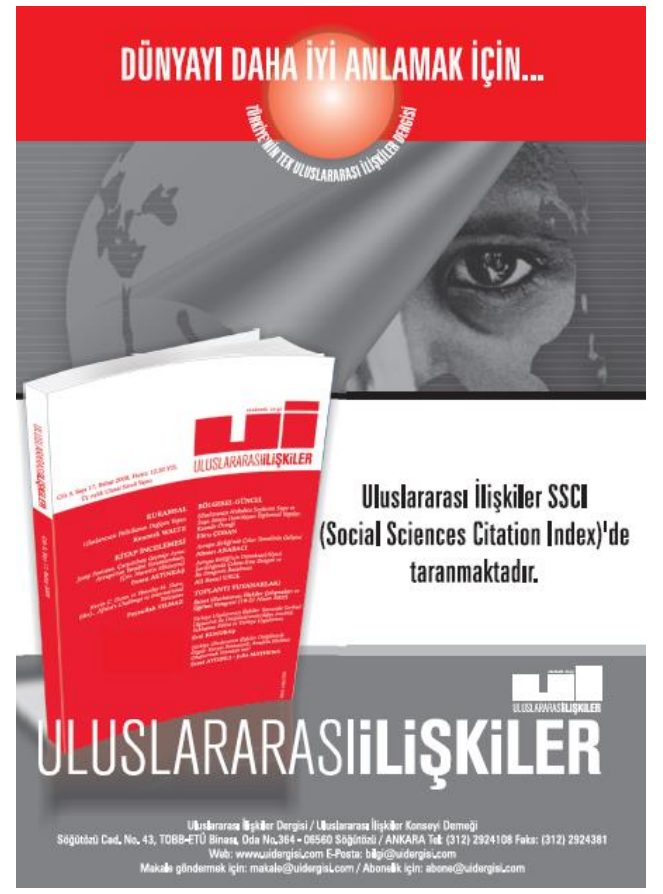

Metodolojik Ulusçuluk ve Türkiye'de Dış Politika Çalışmaları

\author{
Hüsrev TABAK* \\ * Yrd. Doç. Dr., Uluslararası İlişkiler Bölümü, Recep Tayyip \\ Erdoğan Üniversitesi
}

Bu makaleye atıf için: Tabak, Hüsrev, "Metodolojik Ulusçuluk ve Türkiye'de Dış Politika Çalışmaları”, Uluslararası İlişkiler, Cilt 13, Say1 51, 2016, s. 21-39.

Bu makalenin tüm hakları Uluslararası İlişkiler Konseyi Derneği'ne aittir. Önceden yazılı izin alınmadan hiç bir iletişim, kopyalama ya da yayın sistemi kullanılarak yeniden yayımlanamaz, çoğaltılamaz, dağıtılamaz, satılamaz veya herhangi bir şekilde kamunun ücretli/ücretsiz kullanımına sunulamaz. Akademik ve haber amaçlı kısa alıntılar bu kuralın dışındadır.

Aksi belirtilmediği sürece Uluslararası Illişkiler'de yayınlanan yazılarda belirtilen fikirler yalnızca yazarına/yazarlarına aittir. UİK Derneğini, editörleri ve diğer yazarları bağlamaz. 


\title{
Metodolojik Ulusçuluk ve Türkiye'de Dış Politika Çalışmaları
}

\author{
Hüsrev TABAK \\ Yrd. Doç. Dr., Uluslararası İlişkiler Bölümü, İIBF, Recep Tayyip Erdoğan Ünivesitesi, Rize. \\ Email: husrev.tabak@erdogan.edu.tr
}

\section{ÖZET}

Metodolojik Ulusçuluk, beşeri dünyanın, kendini ulus-devletler olarak organize etmiş uluslardan müteșekkil bir yapı olarak tahayyül edilmesi ve yazılması olarak tanımlanan ve sosyal bilimlerin tümü için sonuçları olan bir akademik yazım problemidir. Konuya ilişkin özellikle sosyoloji, antropoloji, tarih gibi alanlarda ilgili yanlışın gerek sebeplerini, gerekse doğurduğu kurucu sonuçları ortaya koyucu pek çok çalışma yapılmıştır. Metodolojik ulusçuluk Uluslararası İlişkiler'de de tartışılırken, tartışmalar ilgili pratiklerin Uluslararası İlişkiler için anlamıyla sınırlı kalmıştır. Dış politika çalışmalarındaysa konuya ilişkin derinlemesine bir tartışma yapılmamıştır. Buradan hareketle bu makale, Türkiye'de dış politika çalışmaları örnek incelemesiyle, dış politika çalışmalarındaki metodolojik ulusçuluk pratiklerini ve bunların kurucu etkilerini ortaya koymaya çalışmaktadır.

Anahtar Kelimeler: Metodolojik Ulusçuluk, Dış Politika Çalışmaları, Türk Dış Politikası.

\section{Methodological Nationalism and the Study of Foreign Policy in Turkey}

\begin{abstract}
Methodological nationalism, while defined as imagining and studying a humanity consisting of nations that organizes itself as nation-states, poses a problem for academia with consequences for the entire social sciences. It has long been discussed and debated in the fields of sociology, anthropology and history and people have often sought to unfold the reasons and constitutive consequences of such research misconduct. Methodological nationalism has also been debated in International Relations (IR), yet debates remained limited to methodological nationalisms relevance to the debates on the future of IR. In the study of foreign policy, however, almost no studies have been conducted problematizing methodological nationalism. This study is thus an attempt to unfold the common practices of methodological nationalism in and their consequences for foreign policy research, in the case of the study of foreign policy in Turkey.
\end{abstract}

Keywords: Methodological nationalism, foreign policy research, Turkish foreign policy. 


\section{Giriş}

Metodolojik Ulusçuluk (methodological nationalism), Uluslararası İlişkileri (Uİ) yakından ilgilendiren ancak alanca bir o kadar ilgi gösterilmeyen bir tartışmadır. Uluslararası Politik Sosyoloji ve özellikle küreselleşme ve Uİ’nin geleceği üzerine tartışmaların gelişimiyle görece az da olsa değinilen konu üzerine, dış politika çalışmaları noktasındaysa henüz bir tartışma gündemi oluşmamıştır. Bu boşluktan hareketle bu çalışma, ilk olarak, sosyal bilimlerde önemli bir tartışma konusu olan metodolojik ulusçuluğun genelde Uí, özelde de dış politika çalışmaları açısından anlamı ve sonuçlarını ortaya koymayı hedeflemektedir. İlgili sorgu Türkiye'de dış politika çalışmaları örnek incelemesi ile yapılacaktır. Türkiye tercihi önemlidir çünkü Türkiye'de dış politika çalışmalarında metodolojik ulusçuluğa ilişkin ampirik anlamda bir sorgu olmadığı gibi, ilgili yazın üzerine özellikle akademik yazım alışkanlıklarının kurucu etkileri üzerine bir inceleme de gelişmemiştir. Bu noktadan hareketle çalışma, ikinci olarak, Türkiye'de dış politika yazınında mevcut metodolojik ulusçu bakış açılarının ve ele alışların bir kısmını inceleyerek, bunların epistemolojik ve ontolojik anlamda kurucu etkilerini ortaya koymaya çalışacaktır.

İki temel amaçla hazırlanan bu çalışma üç ana bölümden oluşmaktadır. İlk bölümde metodolojik ulusçuluğun tanımı, hangi akademik pratiklerin metodolojik ulusçuluk olduğu ve sosyal bilimler açısından bunun sonuçları incelenecektir. İkinci bölümde, metodolojik ulusçuluğun Uİ ve dış politika çalışmaları alanları için anlamı ve sonuçları üzerinde durulacaktır. Çalışmanın son bölümünde, Türkiye'de dış politika çalışmaları örnek incelemesiyle, metodolojik ulusçuluğun diş politika çalışmaları için kurucu sonuçları ortaya konulmaya çalışılacaktır.

\section{Metodolojik Ulusçuluk: Tanım, Pratikler ve Sonuçları}

Metodolojik Ulusçuluk modern sosyal bilimlere içkin ve sosyal bilimlerin tümü için sonuçları olan ve çoğunlukla zımnen yapılan bir akademik yazım ve yaklaşım problemidir ve temel anlamda bilimi, akademiyi ve uzman görüşünü ilgilendirmektedir. ${ }^{1}$ Problem kendini sosyal teori kadar ampirik araştırmalarda da göstermekte ve sosyal bilimcilerin ampirik gerçeklik hakkındaki, ilgili araştırma yöntemlerini kullanarak doğruluklarını teyit ettikleri, inançlarına işaret etmektedir. ${ }^{2}$ Metodolojik ulusçuluk bu anlamda metodolojik olduğu kadar epistemolojik ve ontolojik bir sorundur. ${ }^{3}$

Metodoloji noktasında, probleme verilen ismin akla getirebileceğinin aksine ortada, Ulrich Beck'in tabiriyle, "bir ya da daha fazla sosyologun yarattığı, belirgin bir milliyetçilik/ulusçuluk üzerine kurulu, belirgin bir metodoloji” yoktur, kavrama dikkat çekilerek yapılan daha ziyade "sosyolojinin ya da sosyal teorinin sosyolojisidir." ${ }^{3}$ Bu kapsamda metodolojik eleştiriler, metodolojik ulusçuluğun

1 Daniel Chernilo, "The Critique of Methodological Nationalism: Theory and History" Thesis Eleven, Cilt 106, No.1, 2011, s.98-117.

2 Ulrich Beck, "Toward a New Critical Theory with a Cosmopolitan Intent", Constellations, Cilt 10, No.4, 2003, s. 455); Chernilo, "The Critique of Methodological Nationalism".

3 Anna Amelina, et.al. (der), Beyond Methodological Nationalism: Research Methodologies for Cross-Border Studies, New York, Routledge, 2012, s.2.

4 Ulrich Beck ve Natan Sznaider, "Unpacking Cosmopolitanism for the Social Sciences: a research agenda", The British Journal of Sociology, Cilt 57, No.1, 2006, s.3. 
bir tür somutlaştırma, doğallaştırma ${ }^{5}$ ve özcülük ${ }^{6}$ olduğuna dikkat çekmektedirler. ${ }^{7}$ Epistemoloji noktasındaki sorun metodolojik ulusçuluğun temelde bir ampirik bilgi üretim sorunu olmasıdır. $\mathrm{Bu}$ anlamda metodolojik ulusçuluk "sosyal bilimci”nin "sosyal aktör"ün toplumsal gerçeklikleri ve kategorileri somutlaştırma uğraşlarına katkı sunmasıdır. Bu katkı bazen sosyal aktörün kullanabileceği metodolojik ulusçu ampirik bilgiyi üreterek, bazen de sosyal aktörün ürettiği kategorileri verili kabul ederek ve onun üzerine çalışma yaparak gerçekleşir. ${ }^{8} \mathrm{Bu}$ anlamda sosyal bilimci ile sosyal aktör arasında düşünme şekli açısından fark olması önemlidir; aksi takdirde fark sosyal aktör lehine ortadan kalkar. Tarihsel olarak sosyal bilimciler ile sosyal aktör özdeşleşmesi, ontolojik anlamda, örneğin, ulus, etnisite, milliyet, ulus-devlet gibi kategorilerin mutlak gerçeklikler olarak üretilmesi ve kullanılmasıyla sonuçlanmıştır; burada sosyal bilimcinin ürettiği bilimsel bilgi ilgili gerçeklikleri ve kategorileri somutlaştırmak için sosyal aktörlerin hizmetinde olmuştur. ${ }^{9}$ Görüldügü üzere metodolojik ulusçuluk ciddi ve kurucu sonuçlar doğurabilmektedir. Bu sebepledir ki metodolojik ulusçuluk, bir çeşit akademik "günah" ve "kötüye kullanma" sayılmakta ve reddi üzerine sosyal bilimlerde yaygın bir kanı bulunmaktadır. ${ }^{10}$

Kavramı ilk kez ve "ulus-devleti modern sosyal ilişkilerin temel taşıyıcısı" olarak gören hakim sosyolojik yaklaşımları eleştirmek için kullanan Herminio Martins onu şöyle tanımlamaktadır: "Metodolojik ulusçuluk ulusal topluluğun, sosyal bilimlerdeki sorunların ve olayların sınırlarını belirlemek için nihai birim ve sınır koşulu olması pratiğidir." ${ }^{11}$ Kavramın gelişim seyri içerisinde metodolojik ulusçu yaklaşımları Antony Giddens ${ }^{12}$ "ulusu modern toplumun doğal bir temsili" olarak görmeleri ve Antony D. Smith ${ }^{13}$ ise ulusu somutlaştırarak modern siyasal bir ideoloji olarak milliyetçiliğin/ulusçuluğun etkin rolünü yok saymaları sebebiyle eleştirmiştir. 1980’lerde popüler küreselleşme çalışmalarına paralel olarak "ulus-devletin artık modernitenin gerekli bir temsilcisi olmadığı” ve zayıfladığına ilişkin yorumlar çerçevesinde eleştirilen metodolojik ulusçuluk, 2000’lerle birlikte ulus-devletin modern zamandaki hâkim konumu kabul edilerek ve onu metodolojik ulusçuluk yapmadan çalışmanın yolları aranarak çalışılmıştır. ${ }^{14} \mathrm{Bu}$ son dönemde kavrama yönelik eleştirilerin yaygınlaşmasında önemli rolü bulunan Andreas Wimmer ve Nina Glick Schiller, "sosyal bilimler eliyle

5 Chernilo, "The Critique of Methodological Nationalism", s.99

6 Ulrich Beck, "The Cosmopolitan Society and its Enemies", Theory, Culture \& Society, Cilt 19, No.1-2, 2002, s.37.

7 Yazında, metodolojik ulusçuluğun metodolojik bireycilikten "ilham” aldığı ve aralarında benzerlikler olduğu ifade edilmektedir. Bakınız Andreas Wimmer ve Nina Glick Schiller, "Methodological Nationalism and Beyond: Nation-state Building, Migration and the Social Sciences", Global Networks, Cilt 2, No.4, 2002, s.301-334; Daniel Chernilo, "Methodological Nationalism and the Domestic Analogy: classical resources for their critique", Cambridge Review of International Affairs, Cilt 23, No.1, 2010, s.87-106.

8 Ulrich Beck, "Cosmopolitanism as Imagined Communities of Global Risk", American Behavioral Scientist, Cilt 55, No.10, 2011, s.1346-1361.

9 Ibid., s.1347. Bu noktaya Rogers Brubaker da dikkat çekmekte ve sosyal bilimcilerin etnisite ya da ulus gibi toplumsal ve inşa edilmiş kategorileri gerçek ve doğal yapılarmış gibi ele alarak, onların bir sosyal aktör olarak “etnopolitik girişimci”ler (ethnopolitical entrepreneur) eliyle somutlaştırılmalarına katk1 sunduklarını savunmaktadır. Bakınız Rogers Brubaker, Ethnicity Without Groups, Harvard University Press, 2004, s.10.

10 Chernilo, "The Critique of Methodological Nationalism", s.100.

11 Martins'den aktaran, Chernilo, "Social Theory's Methodological Nationalism. Makaleye teknik imkânsızlıklar sebebiyle erişilememiştir. Çalışmanın künyesi şöyledir: Herminio Martins, "Time and Theory in Sociology", John Rex (der). Approaches to Sociology, London, Routledge, 1974, s.246-294.

12 Anthony Giddens, The Nation-State and Violence, Cambridge, Polity Press, 1985.

13 Anthony D. Smith, "Nationalism and Classical Social Theory", British Journal of Sociology, Cilt 34, No.1, 1983, s.19-38.

14 Chernilo, "Methodological Nationalism and the Domestic Analogy", s.89. 
ulus-devletin doğallaştırılması” olarak tanımladıkları metodolojik ulusçuluk noktasında şuna dikkat çekmektedirler:

Bu entelektüel eğilime sahip akademisyenler; ülkelerin karşılaştırmalı çalışmalar için doğal analiz birimleri olduğunu varsaymakta, toplumu ulus-devlet ile bir tutmakta ve ulusal çıarları sosyal bilimlerin de amacı haline getirmektedirler. Metodolojik ulusçuluk birçok akademisyenin kendi ulus-devletiyle kurduğu özdeşleşmeyi göstermekte ve onu güçlendirmektedir. ${ }^{15}$

Nina Glick Schiller, bu yaklaşımı bütünler şekilde kavramı ayrıca "sosyal ve tarihsel süreçleri ulus-devlet sınırları ile sınırlı süreçler olarak çalışan ideolojik bir yönelim” olarak tanımlamaktadır. ${ }^{16}$ Konuya ilişkin önemli çalışmalara imza atan bir diğer isim, Ulrich Beck’e göre metodolojik ulusçuluk toplumu ulus-devlet topluluklarıyla özdeşleştiren, devletleri ve hükümetleri sosyal bilimler araştırmasının temel inceleme konusu yapan -yani eylem kategorilerini analiz kategorisi olarak ele alan- ve insanlığın, kendini ulus-devletler olarak organize etmiş ve diğerlerinden devlet sınırlarıyla ayrılmış, doğal uluslara ayrıldığını varsayan akademik yazım problemidir. ${ }^{17}$ Metodolojik ulusçuluk eleştirisi yazınına ciddi sorgulamalar getiren sosyolog Daniel Chernilo ise kavramı "tarihsel bir süreç olan modern ulus-devletin inşası ile sosyal teorinin temel kavramsal referanslarından toplum fikrinin özdeşleştirilmesi” olarak tanımlamaktadır. ${ }^{18}$

Tanımlardan ortaya çıkan, metodolojik ulusçuluğun hem ampirik hem de sosyal teori çalışmalarınca yapılan bir akademik pratik olduğudur. Bu doğrultuda Wimmer ve Glick Schiller üç temel metodolojik ulusçu eylem kategorisinden bahsetmektedir: modernitenin gelişiminde ulusdevletin ve milliyetçiliğin/ulusçuluğun rolünün görmezden gelinmesi (ignorance), sosyal/toplumsal kategorilerin doğallaştırılması (naturalization) ve ilişkilerin ve toplumsal kategorilerin mekâna kısitlanmasi (territorial limitation). ${ }^{19}$

İlk pratiğe göre sosyal teoride ulus-devletin yükselişi ve temel özellikleri sıklıkla modernitenin yükseliş ve temel özelliklerini açıklamak için kullanılmaktadır ve modern dünyanın oluşumunda milliyetçiliğin/ulusçuluğun ve ulus-devletin önemi ve rolü yadsınmaktadır. ${ }^{20}$

İkinci pratik kategorisi, doğallaştırma, "ulus-devletin doğallaştırılması ve ulusun somutlaştırılması ile sonuçlanan, 'toplum'un zımnen de olsa ulus üzerinden kurgulanması"21 pratiklerinden oluşmaktadır. Bu kapsamda, insanlığın kendini ulus-devletler olarak organize etmiş doğal uluslara ayrıldığı varsayılmakta, topluluklara genelleyici özellikler ithaf edilmekte ve bu hayali "ulusal karakter"ler üzerine çalısma yapılmaktadır. ${ }^{22}$ Buradan hareketle Ulrich Beck "ulusal” sıfatının, kullanıldığı her yerde, özellikle de "analiz birimi ulusal toplum veya ulusal devlet ya da her ikisi birdense", metodolojik ulusçuluğun habercisi

15 Andreas Wimmer ve Nina Glick Schiller, "Methodological Nationalism, the Social Sciences, and the Study of Migration: An Essay in Historical Epistemology", International Migration Review, Cilt 37, No.2, 2003, s.576-610.

16 Bkz. Nina Glick Schiller, "Beyond Methodological Ethnicity: Local and Transnational Pathways of Immigrant Incorporation", Willy Brandt Series of Working Papers in International Migration and Ethnic Relations, Malmö University, 2/08, 2008, s.1-36.

17 Beck, "Toward a New Critical Theory", s.453.

18 Chernilo, "The Critique of Methodological Nationalism", s.99.

19 Wimmer ve Schiller, "Methodological Nationalism and Beyond", s.308.

20 Chernilo, "The Critique of Methodological Nationalism", s.104. Bahse konu pratik, diş politika çalışmaları ve Uluslararası İlişkiler alanlarında rastlanan bir akademik eylem niteliği kazanmamıştır, bu sebeple bu pratiğe ilişkin anlatı sınırlı tutulmuştur.

21 Ibid, s.103.

22 Beck, "Toward a New Critical Theory", s.453-455; Wimmer ve Schiller, "Methodological Nationalism and Beyond", s.308. 
olabileceğini savunmaktadır. ${ }^{23}$ Doğallaştırma kapsamında ulusal veriler, söylemler, gündemler, bağlılıklar ve tarihler sorunsallaştırılmadan verili olarak kullanılmaktadır. ${ }^{24}$ Bununla ilişkili olarak, özellikle de sosyal antropoloji alanında sık görülen bir doğallaştırıcı pratik, Herderci ${ }^{25}$ kültürel coğrafya tahayyülünden hareketle her topluluğun onu diğerlerinden ayıran kendine has özelliklerinin ve kültürünün olduğunun savunulması ve haritaların münferit ve "yerli” halklardan müteşekkil ve onlar arasında bölünmüş mekânlar olarak anlaşılmasıdır. ${ }^{26} \mathrm{Bu}$ kendini sıklıkla ulus ya da etnisite kategorilerinin tarihsel/kadim yapılar olarak ve verili ele alınmaları şeklinde gösterir. Bir diğer doğallaştırıcı pratik, Chernilo’nun dikkat çektiği ve Uİ’yi de ilgilendirdiği üzere, dünyanın belirsiz sayıdaki resmi olarak karşılaştırılabilir ulusal birimlere bölünmüş olduğu ve uluslararası sistemin bugün o birimlerin yaklaşık 200 'ünden oluştuğu yönündeki argümanlardır. ${ }^{27}$

Üçüncü pratik kategorisi, mekâna kısıtlama, sosyal hayatın her alanının ulus-devlet içerisine hapsedilmesi, sosyal bilimlerin analitik odağının ulus-devlet sınırlarına indirgenmesi, ulus-devlet sınırları içerisindeki süreçlerin sınırların dışarısındaki süreçlerden farklı olduğunun düşünülmesi ve ulusal sınırları aşan ya da ulusal olarak tanılanamayan her tür ilişkinin analitik olarak yok sayılması benzeri pratiklerden oluşmaktadır. ${ }^{28}$ Buna göre ulus-devletler mekânsal olarak tanımlanmakta ve ulus ile toprak arasında birbirlerini karşılıklı sınırlandırıcı bir ilişki kurulmakta; ulus, devlet içerisinde ve ona ait olan toprak üzerinde yaşayan ulusal toplumun bir "kabı” olarak tasavvur edilmektedir. ${ }^{29}$ Benzer şekilde, bu kapsamda, dünya üzerinde devlet gibi toplum da tekil değil çoğul/çoklu olarak kabul edilmekte, devlet ve toplumlar ulusal ve uluslararası ikiliğinde tahayyül edilmektedir. ${ }^{30}$ Ayrıca, ulusal olarak toplanmış ve üretilmiş istatistiki veriler analiz kategorisi yapılmakta, ampirik çalışmalarda veri toplama ulusal olarak sinırlandırılmaktadır. ${ }^{31}$

Tüm bu tanımlar ve pratikler ile birlikte düşünüldüğünde, metodolojik ulusçuluğun sonuçları, sosyal bilimcilerin gözlemledikleri sosyal dünya üzerindeki kurucu etkilerine denk gelmektedir. ${ }^{32} \mathrm{Bu}$ anlamda sosyal bilimcilerin metodolojik ulusçuluğu, epistemolojik olduğu kadar ontolojik sonuçlar da doğurmaktadır.

Ontolojik zeminde sosyal bilimciler, birer eylem kategorisi olan ulus, etnisite, ulusdevlet gibi birimlerin ${ }^{33}$ somut varlıklar olarak tahayyül edilmelerine ve ulusal gerçeklikler olarak

23 Beck ve Sznaider, "Unpacking Cosmopolitanism for the Social Sciences", s.3.

24 Wimmer ve Schiller, "Methodological Nationalism and Beyond", s.308; Amelina et al., Beyond Methodological Nationalism, s.2.

25 Johann Gottfried (von) Herder (1744 -1803), antropoloji alanının kurucularından. Herder dünyanın kültürel olarak ayrışmış toplumlardan/halklardan müteşekkil bir yapı olduğunu, toplum üyelerinin birbirine bağlı olduklarını ve ortak kimliği paylaştıklarını; bu sebeple de tarihsel ve sosyal gözlem ve araştırma için uygun bir analiz birimi oluşturduklarını varsaymaktadır. Herder'e göre halklar, ya da onun takipçilerinin kullandıkları şekliyle uluslar ve etnisiteler, perennial yani kadim ve tarihseldirler, verili doğaları vardır, kendi içlerinde homojen ve birbirlerinden kesin kültürel çizgilerle ayrilırlar, sabit kimliğe sahiptirler ve doğal/organik yapılardır. Bakınız Andreas Wimmer, "Herder's Heritage and the Boundary-Making Approach: Studying Ethnicity in Immigrant Societies", Sociological Theory, Cilt 27, No.3, 2009, s.246-7.

26 David Gellner, "Uncomfortable Antinomies: going beyond methodological nationalism in social and cultural anthropology", Austrian Academy of Sciences Working Papers in Social Anthropology, Say1 24, 2012. s.2-3.

27 Chernilo, "The Critique of Methodological Nationalism", s.104-5.

28 Wimmer ve Schiller, "Methodological Nationalism and Beyond", s.308; Chernilo, "The Critique of Methodological Nationalism", s.103.

29 Ulrich Beck, "The Cosmopolitan Perspective: Sociology in the Second Age of Modernity", British Journal of Sociology, Cilt 51, No.1, 2000, s.79-107.

30 Beck, "Toward a New Critical Theory”, s.453-455.

31 Amelina et al., Beyond Methodological Nationalism, s.2.

32 Wimmer ve Schiller, "Methodological Nationalism and Beyond", s.302.

33 Beck ve Sznaider, "Unpacking Cosmopolitanism for the Social Sciences", s.4. 
üretilmelerine bilimsel katkı sağlamaktadırlar. Bu noktada sosyal bilimcinin ürettiği metodolojik ulusçu "bilimsel” bilgi sosyal dünyayı (özellikle de ulusu ve ulus-devleti) somutlaştırmak ve ulusal yapıları sürdürmek için sosyal aktörlerin hizmetine sunulmuş olmaktadır. ${ }^{34}$ Ayrıca, sosyal aktörce tanımlanan ulusal çıkarlar, sosyal bilimcinin metodolojik ulusçuluğu sebebiyle sosyal bilimlerin de amacı haline gelmekte ${ }^{35}$, sosyal bilimcinin kendi ulus-devletiyle kurduğu özdeşleşme onu analitik bir faile dönüştürmektedir. ${ }^{36}$ Öyleyse, epistemolojik anlamda metodolojik ulusçuluğun sonuçlarını sosyal bilimcinin sosyal dünyayı şekillendirici ya da şekillenmesine katkı sunucu ve araştırma yöntemleri kullanılarak doğruluklarını teyit edilmiş "bilgi üretimi”" temsil etmektedir. Ulrich Beck bu durumu şöyle ifade etmektedir: "Ulus-devlet bir ruh halidir. Metodolojik ulusçuluğa bel bağlayan sosyal bilimlerce üretilen bilgi sayesinde, bunu algılamayı engelleyen duvarlar örülmekte ... teşvik edilmekte, meşrulaştırılmakta ve sağlamlaştırılmaktadır." ${ }^{37}$ Bunun sonucuysa, Robertson ve Dale'in ifadesiyle, 'açıklayabildiklerimiz en kapsamlı gerçekliğin 'ulusal', ya da en iyi ihtimalle 'uluslararası', olması"dır. ${ }^{38}$ Buradan hareketle, ulus-devlet anlayışının en revaçta olduğu günlerde bile modern dünyanın ne kadar da ulusötesi bir yapı olduğunun görülmesini engelleyen, modern yaşama içkin bir ulusötesi karakterin varlığını gölgeleyen, "mevcut kozmopolit süreçleri tanımlanmamış olarak $\operatorname{birak}(\mathrm{an})$ ve ulusal epistemolojileri güçlendir(erek)... onu yeniden üretilen bir süreç haline getiren" ${ }^{39}$ de metodolojik ulusçuluktur. ${ }^{40}$

\section{Metodolojik Ulusçuluğun Ui ve Dış Politika Çalışmaları için Anlamı ve Sonuçları}

Metodolojik ulusçuluğun "gerçek" bir problem olduğuna ilişkin sosyal bilimlerdeki yaygın kanıyı gördük. Benzer kanılar, bu problemin Uİ için anlamı ve sonuçları olduğuna ilişkin de vardır. ${ }^{41}$ Öyle ki, Gunther Hellmann'ın ifadesiyle, kendisine "Uluslar arası İlişkiler” diyen akademik bir alan için metodolojik ulusçuluk olağan ve hatta beklenen bir pratiktir. ${ }^{42}$ Bunu teyit eder biçimde metodolojik ulusçuluğa ilişkin temel çalışma sahiplerinin tümü çalışmalarında konunun Uİ'deki yansımalarına değinmişlerdir.

Metodolojik ulusçuluğun Uİde olağan bir pratik oluşunu Daniel Chernilo temel olarak şuna bağlamaktadır. Yirminci yüzyılda self-determinasyon ilkesi çerçevesinde halkların meşru bir zeminde

34 Amelina et al., Beyond Methodological Nationalism, s.9.

35 Wimmer ve Schiller, "Methodological Nationalism and Beyond", s.302.

36 Chernilo, "The Critique of Methodological Nationalism", s.99.

37 Beck, "Toward a New Critical Theory", s.463.

38 Susan Robertson ve Roger Dale, "Researching Education in a Globalising Era: Beyond Methodological Nationalism, Methodological Statism, Methodological Educationism and Spatial Fetishism", Centre for Globalisation, Education and Societies, University of Bristol, http://www.bris.ac.uk/education/people/ academicStaff/edslr/publications/15slr/ (Erişim Tarihi: 22 Kasım 2015).

39 Beck ve Sznaider, "Unpacking Cosmopolitanism for the Social Sciences", s.5.

40 Wimmer ve Schiller, "Methodological Nationalism and Beyond", s.302.

41 Kavramın Türkçe Uİ çalışmalarında "yöntemsel ulusçuluk" şeklindeki kullanımı için bakınız Faruk Yalvaç, "Devlet", Atila Eralp (der) Devlet ve Ötesi: Uluslararası İlişkilerde Temel Kavramlar, İstanbul, İletişim Yayınları, 2005, s.31; Faruk Yalvaç, "Tarihsel Sosyoloji ve Uluslararası İlişkiler: Jeopolitik, Kapitalizm ve Devletler Sistemi”, Uluslararası İlişkiler, Cilt 10, No.38, 2013, s.6.

42 Gunther Hellmann, "Methodological Transnationalism-Europe's Offering to Global IR?", European Review of International Studies, Cilt 1, No.1, 2014, s.28. Hellman bu çalışmasında ayrıca Uluslararası İlişkiler'de ekolleşme ve bölgeselleşmenin metodolojik ulusçuluk konusunda yansımaları olduğu kadar metodolojik ulusçuluğu aşma uğraşlarına da karşılık geldiği yönünde önemli bir tartı̧ma yapmaktadır. 
kendi ulus-devletlerini kurmaları ve bunu takiben bir sosyal aktör olarak ulus-devletlerin bu zeminde kendilerini homojen yapılar olarak sunmaları, tüm bu süreci anlamaya çalışan akademisyenleri ulus-devletleri somut yapılar olarak ele alma sonucuna götürmüştür. Ayrıca Milletler Cemiyeti ve Birleşmiş Milletler gibi o güne kadar ortaya çıkmamış ve özünde ulus-devletleri egemen aktörler olarak tanımlayan yapıların ortaya çıkması, ulus-devletin her seviyede önemli addedilen bir aktör hale gelmesiyle sonuçlanmıştır. ${ }^{43} \mathrm{Bu}$ da yeni ilişki zeminini açıklamaya çalışan akademisyenlerde ulusdevleti ve (ulus)devletler-arası sistemi doğal ve önemli yapılar olarak ele alma eğilimi yaratmıştır. ${ }^{44}$

Bu zeminden hareketle kavram Uİ'de kendini, Wimmer ve Glick Schiller'ın da dikkat çektiği üzere, temel olarak iki tür ampirik pratik olarak göstermiştir. İlki ulus-devletlerin beşeri ve uluslar arası dünyayı ve siyaseti organize etmek ve çalışmak için uygun yapılar oldukları varsayımı ile ulusdevletlerin egemen, birbirinden mutlak olarak ayrışan ve geçirgen olmayan birimler olarak anlaşıldığ 1 bir uluslararası sistem tasavvuru ${ }^{45}$ yoluyla ulus-devlet ve uluslararası sistemin doğallaştırılmasıdır. ${ }^{46}$ Bunun ampirik tezahürü ise, daha önce de değindiğimiz üzere, dünyanın belirsiz sayıdaki resmi olarak karşılaştırılabilir ulusal birimlere bölünmüş olduğu ve uluslararası sistemin bugün o birimlerin yaklaşık 200'ünden oluştuğu yönündeki anlayış ve yazımdır. ${ }^{47}$ İkinci pratik Uİde mevcut iç ve dış politika, ulusal ve uluslararası ilişkiler gibi içerisi ve dışarısı ayrımları ve ikiliklerinin oluşmasıyla sonuçlanan, ilişkileri ve kategorileri mekâna kısıtlamadır. ${ }^{48}$ Mekâna kısıtlama pratikleriyle ise ulusdevlet içerisindeki süreçlerin dışındaki süreçlerden farklı olduğu savunulmakta, devletlerin ilişkileri iç ve uluslararası ilişkiler olarak bölünmekte, devletin dış ilişkileri devletten devlete ilişkiler olarak kurulurken, örneğin sınır-ötesi pratikler görünmez kılınmaktadır. ${ }^{49}$ Her iki pratik de Uİde kendini, kavramsal incelemeler (iç, dış, ulusal, uluslararası), teori inşası (devlet üzerine ve etrafında), vaka tercihleri ve veri tanımlamaları (karşılaştırmalı çalışmalar ve ulusal olarak sınırlandırılmış veriler) ile analiz birimi ve seviyesi tercihi gibi akademik pratiklerin tümünde göstermektedir. ${ }^{50}$

Uİ’e mevcut metodolojik ulusçuluğa ilişkin bu pratik kategorilerini de aşan ve Uİ’nin kendi metodolojik ulusçuluğu olarak tanımlanan ${ }^{51}$ bir tartışma vardır; yerelden uyarlama (domestic analogy). Buna göre, "yerel toplum içerisindeki bireylerin tecrübelerinden hareketle devletler de, ortak güçlerinin farkına varabildikleri sürece, tıpkı bireyler gibi düzenli bir sosyal hayat inşa” edebileceklerdir. ${ }^{52}$ Yani yerelden uyarlama'ya göre uluslararası toplumun yapısı ulusal toplumların iç örgütlenmelerinden hareketle anlaşılabilir ve uluslararası ilişkiler "bireysel ulus-devletler arasındaki etkileşimlerin sonucu olarak" çalışılabilirdir. ${ }^{53}$ Ancak kavrama ilişkin eleştiriler onu "uluslararası” nın özgün doğasını kavramak

$43 \mathrm{Bu}$ aynı zamanda ulus-devleti modern dünya sisteminin ana siyasi kurumu ve temel aktörü haline getirmiştir. Ulus-devlet ve ulus-devletler sistemine ilişkin önemli bir eleştiri için bakınız William Robinson, "Beyond Nation-State Paradigms: Globalization, Sociology, and the Challenge of Transnational Studies", Sociological Forum, Cilt 13, No.4, 1998, s.561-594.

44 Chernilo, "The Critique of Methodological Nationalism", s.108.

45 Bilardo topu modeli bu öngörüyü taşımaktadır. Bakınız Eric Wolf, Europe and the People Without History, Berkeley, University of California Press, 1982, s.6; Arnold Wolfers, Discord and Collaboration: Essays on International Politics, Baltimore, The John Hopkins Press, 1962, s.19.

46 Wimmer ve Schiller, "Methodological Nationalism and Beyond", s.304-5.

47 Chernilo, "The Critique of Methodological Nationalism", s.104.

48 Beck, "Toward a New Critical Theory", s.456; Edgar Grande, "Cosmopolitan Political Science", The British Journal of Sociology, Cilt 57, No.1, 2006, s.97-8.

49 Wimmer ve Schiller, "Methodological Nationalism and Beyond", s.307-8.

50 Hellmann, "Methodological Transnationalism", s.28.

51 Chernilo, "Methodological Nationalism and the Domestic Analogy", s.91.

52 Ibid, s.91-2.

53 Ibid, s.93. 
ve açıklamak konusunda başarısız görmektedir; çünkü eleştirilere göre uluslararası, "toplumsal ilişkilerden 'soyutlanmış' bir kategori” olarak incelenmeli ve otonom bir sosyal ilişkiler sahası olarak anlaşılmalıdır. ${ }^{54} \mathrm{Bu}$ otonom saha öngörüsü önemlidir, çünkü bu alandaki düşünürler "uluslararasının özgüllüğünü iç toplumdan olan farklılığı temeli üzerine inşa etmişler” ve onu “zamansız ve uzamsız" ve düzen sağlayacak bir otoriteden yoksun olarak düşünmüşlerdir. ${ }^{55}$ Ancak, yerelden uyarlama' ya ilişkin eleştiriler sosyal bilimlerde tanımlandığı şekliyle metodolojik ulusçuluğu aşmak konusunda başarılı değillerdir, çünkü "devletler arası otonom sistem” öngörüsü hemen yukarıda sıralanan doğallaştırma ve mekâna kısıtlama pratiklerinin (ulusal/uluslararası ikiliği ve egemen ve geçirgen olmayan devletler kabulü gibi ${ }^{56}$ ) sürekli tekrarlanmasıyla sonuçlanmaktadır.

Uİ'de metodolojik ulusçuluğa ilişkin diğer bir ayırt edici örnek, bireyin, gündelik hayatın ve aidiyetin Uİ'deki anlamının sorgulandığı “Kim nereye aittir?” sorusuna verilen cevaptır. Buna göre, Uİ'de devletler ön planda olduğundan, bireyler devletlerin sınırları içerisinde görünmek durumundadırlar. Bir diğer anlatımla, Uİde insanlar "devlet içerisindeki insanlar” olarak kurgulanmışlardır ve ulusdevletler bu insanları vatandaşları olarak yeniden kurmaktadırlar. İnsanlar, bu sebeple, kendi ulusdevletlerine aittirler. Kendi devletlerinin dışında bulunanlarsa, örneğin göçmen iseler, günlük hayattaki 'uluslararası'nı temsil ederken, Uİ içerisindeki iç ve $d$ ış ayrımını, yani yerel ve uluslararası ayrımını, görünür kılmaktadırlar. Bir devlette vatandaş ile göçmen bir araya geldiğindeyse yerel ve uluslararası bir araya gelmekte, içerisi ve dışarısı arasındaki sınırın nerede çizileceğine ilişkin çatışma her gün sürekli tekrarlanmaktadır. ${ }^{57}$

Bu örnekle de teyit edildiği üzere, Uİ açısından metodolojik ulusçuluk, ulusal/uluslararası ikiliğinin analitik bir ayrımdan daha fazlasını temsil ederek somut bir ayrıma dönmesi noktasında kurucu bir işlev görmektedir. ${ }^{58}$ Son olarak, metodolojik ulusçuluk analiz seviyesi ve analiz birimi tartışmaları yoluyla ulus-devletin analitik bir kategori olarak somutlaşmasında ve temel aktör olarak kurulmasında da etkili olmuştur.

Peki, metodolojik ulusçuluğun dış politika çalışmaları için anlamı ve sonuçları nelerdir? "Dış" politika çalışması, yukarıda bahsettiğimiz iç/dış ikiliği öngörüsünden ötürü, adı gereği metodolojik ulusçuluğu çağrıştırmaktadırve bu minvalde Uİ içerisinde ampirikanlamda bu ikiliğin sürdürülmesinde ve somutlaştırılmasında, her ne kadar ikiliği birleştirici çalışmalar mevcut da olsa, önemli bir rol oynamaktadır. Ancak dış politika çalışmasının metodolojik ulusçulukla ilişkisini bununla bırakmak, özellikle de tarih, sosyoloji ya da karşılaştırmalı siyaset alanlarındakine benzer pratiklerin dış politika alanında da yaygın olduğu düşünüldüğünde, diğer kurucu etkilerin görmezden gelinmesine yol

54 Yalvaç, "Tarihsel Sosyoloji ve Uluslararası İlişkiler", s. 6.

55 Ibid.

$56 \mathrm{Bu}$ anlamda, örneğin, Uİ'de ulus-devlete ilişkin yapılan bilardo topu benzetmesi önemlidir. Keza, bu yolla ulus-devletin "kapalı, geçirgen olmayan (impermeable) ve egemen bir birim olarak bir-diğerinden mutlak olarak ayrıştığı" savunulmakta, ulus-devletin temel aktör olduğu çok-devletli bir uluslararası sistem kurgusu inşa edilmektedir. Bkz. Wolfers, Discord and Collaboration, s.19. Antropolog Eric Wolf sosyal bilimlerin genelindeki benzer bir eğilimden şöylece bahsetmektedir: "Bir şeylere verilen isimleri (somut) şeylere dönüştürerek doğru olmayan gerçeklikler yaratıyoruz. Uluslara, topluluklara ya da kültürlere içeride homojen ve dışarıdan kesin çizgilerle ayrılabilen kapalı nesneler olarak davranarak, dünyayı varlıkların (entities) sert ve yuvarlak bilardo topları misali birbirlerine çarpıp uzaklaştıkları küresel bir bilardo masasına dönüştürüyoruz. Wolf, Europe and the People Without History, s.6.

57 Rebecca Ehata, "Not really 'one of us'? IR, autochthony and the borders of belonging", A paper presented at the 6th Global Conference on Pluralism, Inclusion, and Citizenship, Prague, March 2011. http://bisadev.smartdata. co.uk/index.php/component/bisa/?task=download_paper\&format=raw\&passed_paper_id=224 (Erişim Tarihi: 1 Eylül 2015).

58 Beck, "Toward a New Critical Theory", s.458. 
açabilir. Bu anlamda dış politika çalışmaları sıklıkla sosyal aktör hizmetine metodolojik ulusçu "bilgi sunma” (epistemoloji) ve sosyal aktörce üretilmiş kategorileri olumlama ve somutlaştırılmasına katkı sunma (ontoloji) pratiklerine şahit olmaktadır. Buna göre akademisyenler sıklıkla sosyal aktör ya da etnopolitik girişimci ${ }^{59}$ rolüne bürünmekte, beşeri dünyanın kendi aralarında ilişki geliştiren uluslardan müteşekkil ve onlar arasında bölünmüş mekânlar olarak anlaşılmasında ve dolayısıyla da etnisite ya da ulus gibi toplumsal ve inşa edilmiş kategorilerin gerçek ve doğal birer yapılarmış gibi ele alınmaları ve somutlaştırılmalarında kurucu bir rol üstlenmektedirler. Dahası ve bununla ilişkili olarak, dış politika çalışmaları sıklıkla 'ulusal/milli' sıfatının yaygın kullanımı sonucu topluluklara genelleyici ve devletle özdeşleştirici ${ }^{60}$ özellikler ithaf etmektedir; örneğin Alman dış politikası, milli dış politika, milli savunma politikası vb.

\section{Türkiye'de Dış Politika Çalışmaları ve Metodolojik Ulusçuluk}

Türkiye'de dış politika çalışmalarında tekil metodolojik ulusçu pratikler olmakla birlikte, bu çalışmada analiz, pratiğin olağan bir uygulama olarak öne çıktığı ve alanın genelindeki pratikleri temsil yeterlilikleri bulunan dört yazın teması üzerinden yürütülecektir. Bunlar; "milli dış politika dönemi” yazımı, "dış Türkler politikası” yazımı, "medeniyet merkezli dış politika” yazımı ve "Türk dış politikası" yazımıdır.

\section{“Milli Dış Politika Dönemi” Yazımı}

Bu dönem Kemal Atatürk'ün “Türk ulusal kurtuluş mücadelesi”ni başlattığı tarih olarak yazılan 1919 ila yine Atatürk’ün 1938 yılında ölümüne kadar geçen süredeki dış politika eylemliliklerini kapsamaktadır. Dönemin temel anlatıları arasında “Türk devleti”nin bağımsızlık mücadelesi, milli sınırların korunmasına yönelik uğraşları ve kendine medeni devletler arasında yer araması vardır. $\mathrm{Bu}$ anlamda sıklıkla klasik "milli tarih" anlatısının takip edildiği ve sosyal aktör olarak politika yapıcıların ürettikleri kategorilerin ve bakış açılarının, akademisyenlerce de aynen alınıp kullanıldığı görülmektedir. Birkaçörnek vermek gerekirse;

Atatürk devrinde izlenen dış politikanın, milletlerarası münasebetleri etkiliyen unsurları Türkiye'nin milli çıarları ile en iyi şekilde bağdaştıran dış politika olduğu kanısındayız. ${ }^{61}$

Atatürk'ün dış politika ilkeleri, onun dünya görüşünü yansıtır. Bu dünya görüşünü üç noktada toplamak mümkündür: 'Tam bağımsızlık', 'Ulusal Egemenlik', ve 'Batılılaşmak' olup, bir yerde Milli Mücadele'nin ideolojik altyapısını oluşturur. Bu ilkeler Misak-ı Milli sınırları içinde Lausanne'dan önceki ve sonraki devrede yürütülen siyasal mücadelenin temel hedefini oluşturur. Dış politikanın temelini ve hedeflerini Misak-ı Milli ilkeleri açıklar. Misak-ı Milli, ülke içinde ve dışında Türk milletinin dayandığı temel ilkelerdir. ${ }^{62}$

Mustafa Kemal Paşa’nın liderliğinde başlayan Milli Mücadele hareketinin temel amacı... Osmanlı devletinin enkazı ve yıkıntılarından Türk olan kısımları kurtarıp özünde Avrupa modeline uygun bağımsız bir Türk Milli devleti kurmaktı. Milli Mücâdele döneminde Misâk-ı Millı̂de ifâdesini bulan

59 Bakınız Brubaker, Ethnicity Without Groups, s.10.

60 Beck, "Toward a New Critical Theory", s.453.

61 Mehmet Gönlübol, Atatürk ve Türkiye'nin Dış Politikası (1919-1938), Atatürk Araştırma Merkezi Yayınları, Ankara, 1997, s.148.

62 Hasan Berke Dilan, Atatürk Dönemi Türkiye'nin Dış Politikası (1923-1939), Alfa Yayınları, İstanbul, 1998, s.3-4. Dilan bu sınıflandırmayı hemen aşağıda değindiğimiz Sadi Irmak'ın çalışmasına referansla yapmaktadır. 
bu temel amaç, sınırlı ve gerçekçi, ama haklılığı inkâr edilemeyecek bir hedefti ... Milli Mücadele’nin dış politikasının temel niteliği, bu gerçekçiliği ve hedeflerinin tespitindeki ustalığıydı. ${ }^{63}$

$\mathrm{Bu}$ gerçekçi değerlendirme doğrultusunda Türk Milleti, Milli Mücadele döneminde, verilen karara uygun olarak, Atatürk'ün önderliğinde, ilgili kişi ve kuruluşların da katkılarıyla son derece başarılı bir dış politika izlemiştir. ${ }^{64}$

Anlatılar ki benzerlerine alanda üretilen tezler ve bireysel makaleler ile kitaplarda sıkça rastlanmaktadır, açık bir şekilde akademisyenlerin kendi ulus-devletiyle kurduğu özdeşleşmeyi göstermektedir. Alıntılarda ayrıca millet ve devlet özdeşleştirilirken, ülkenin ulusal çıkarları teyit edilmekte ve desteklenmektedir. Dış politika çalışmaları yapan bu sosyal bilimcilerdeki eğilimin, döneme ilişkin metinler kaleme alan sosyal aktörlerde de olduğunu görüyoruz - ki bu sosyal bilimci ile sosyal aktör arasındaki farkın ortadan kalktığı bir durumun da göstergesidir. Döneme ilişkin kaynakçalarda kendine sıkça yer bulan iki çalışmadan birer alıntıya yer verelim:

Biliyoruz ki Türk milletinin büyük şerefi olan ve aynı zamanda Türk dehasının bir ifadesi olan "Yurtta barış, Cihanda barış" formülü Mustafa Kemal'indir. Biliyoruz ki dünya yavaş yavaş Mustafa Kemal' in bu mübarek formülünü anlama yolundadır. ${ }^{65}$

Ata’nın bir büyüklüğü ve o zamana kadar memleket mukadderatına hakim olmuş ve zamanının parlak bir adamı gibi görülmüş devlet adamlarının hiçbirine nasip olmamış bir imtiyazı vardır. O... Türk’ün özyurdunu teşkil eden yerlerin, medeni milletler yanında yeri olabilmesi için ne yapılmak gerektiğini de düşünmüş, planlamış ve yavaş yavaş, imkan ve şartların müsaadesi nispetinde, bunları uygulamıştır. ${ }^{66}$

İlk alıntı, eski başbakanlardan ve tıp profesörü Sadi Irmak’a, ikincisi ise emekli büyükelçi Aptülahat Akşin'e aittir ve her iki metin de döneme ilişkin dış politika yazınını etkilemişlerdir. Birer sosyal aktör olarak Irmak ve Akşin ile yukarıda alıntılarına yer verdiğimiz sosyal bilimciler arasındaki yaklaşım ve rol benzerliği sosyal bilimcilerde açık bir metodolojik ulusçu yaklaşımın varlığının göstergesidir. $\mathrm{Bu}$ rol benzerliği aynı zamanda sosyal aktörlerce ve milli tarih yazımınca üretilmiş kategoriler, söylemler, bağlılıklar ve tarihlerin dış politika yazınınca olumlanması ve üretilen gerçekliklerin somutlaşmasına dolaylı da olsa katkı sunulması anlamına gelmektedir.

$\mathrm{Bu}$ konuda son olarak, dış politika özelinde sosyal bilimci, sosyal aktör ve ulus/ulus-devlet arasındaki özdeşleşmenin yayınlarında sıklıkla kendine yer bulduğu bilimsel dergilere değinmek gerekir. İsmini sıraladığımız dergilerde yayımlanmış ve sosyal bilimcilerin bilimsel titirleriyle yayınladıkları onlarca makalede bu özdeşleşme açıkça gözlemlenebilmektedir: Askeri Tarih Bülteni, Atatürk Araştırma Merkezi Dergisi, Atatürk Yolu Dergisi, Atatürkçü Düşünce, Belgelerle Türk Tarihi Dergisi, Kara Harp Okulu Bilim Dergisi ve diğerleri. Bilimsel yayın olarak yayımlanan bu dergiler yoluyla, sosyal bilimciler (Uİ akademisyenleri) hem sosyal aktör hizmetine metodolojik ulusçu "bilimsel" bilgi hem de sosyal aktörce üretilmiş kategorilerin somutlaşmalarına katkı sunmuşlardır. Ancak "milli dış politika" dönemine ait metodolojik ulusçu bilgi üretimi hem farklı akademik dergilerde hem de bağımsız yayınevlerince yayınlanmış makale ve kitaplarla da sürmüştür/sürmektedir.

63 Yusuf Sarınay, “Atatürk’ten Günümüze Türk Dış Politikası Hakkında Genel Bir Değerlendirme”, Atatürk Araştırma Merkezi Dergisi, Cilt 16, No.48, 2000, s.1-16.

64 Atilla Sandıkl1, Atatürk'ün Dış Politika Stratejisi: Hedefler ve Prensipler, Bilgesam Yay, İstanbul, 2014, s.55.

65 Sadi Irmak, “Atatürk'ün Dış Politika İlkeleri”, Atatürk Araştırma Merkezi Dergisi, Cilt 3, No.9, 1987, s.491.

66 Aptülahat Akşin, Atatürk'ün Dış Politika İlkeleri ve Diplomasisi, Türk Tarih Kurumu Basımevi, Ankara, 1991, s.23. Bu kitabın ilk baskısı iki cilt halinde sırasıyla 1964 ve 1966 yıllarında yayınlanmıştır. 


\section{“Dış Türkler Politikası” Yazımı}

İkinci yaygın metodolojik ulusçu pratikler "dış Türkler politikası" yazımı kapsamında ortaya çıkmaktadır. Bu yazınca Türkiye’nin, adına “dış Türkler” denilen bir politikasının olduğu ifade edilmekte ve bu minvalde Türkiye'nin kendi ulusal sınırları dışında gerek azınlık gerekse devlet olarak yaşadığı iddia olunan ve kendilerine "Türk" denilen topluluklarla ilişkileri incelenmektedir. ${ }^{67}$

Bu politika analizi kapsamda, örneğin Meşkure Yılmaz’ın sonradan kitaplaştırılmış doktora tezinde ifade olunduğu üzere, Türkiye'nin şu devletler ve topluluklarla ilişkileri incelenmektedir: Türk Cumhuriyetleri (Azerbaycan, Özbekistan, Kazakistan, Türkmenistan, Kırgızistan), Rusya Federasyonu İçerisinde Yaşayan Türkler (Altay, Başkurdistan, Çuvaşistan, Dağıstan, Gagauz, Hakas, Kabarday Balkar, Saka, Tataristan, Tuva, Karakalpak özerk cumhuriyetleri), Kıbrıs Türkleri (KKTC), Batı Trakya Türkleri, Bulgaristan Türkleri, Yugoslavya, Makedonya ve Romanya Türkleri, Irak Türkleri, Suriye Türkleri, Kırım Türkleri, Doğu Türkistan Türkleri ve Güney Türkistan Türkleri (Afganistan). ${ }^{68}$ Radiye Funda Karadeniz de “Türkiye dış politikasında dış Türkleri ne zaman hatırlıyor, ne zaman unutuyor?” sorusuna cevap aradığı Türk Dış Politikasında Dış Türkler isimli yayınlanmamış doktora çalışmasında Türkiye'nin Batı Trakya Türkleri, Bulgar Türkleri ve Irak Türkmenleri ile cumhuriyetten günümüze kadarki ilişkilerini karşılaştırmalı olarak inceliyor. ${ }^{69}$

Konuya ilişkin bir kısmı yine kitaplaştırılan daha pek çok yüksek lisans tezi ve akademik makale bulunmaktadır ${ }^{70}$ ancak Yılmaz ve Karadeniz'in tezlerinde de görüldüğü üzere çalışmaların geneli Türkiye'yi ve ilişki geliştirilen karşı topluluğu/devleti sorgusuz biçimde "Türk devleti/ topluluğu” olarak kodlarken Türkiye'yi diğer Türk devletleri ve topluluklarının "merkezinde” tahayyül etmektedir. ${ }^{71} \mathrm{Bu}$ minvalde, ilgili politika Türkiye merkezli bir tasavvur olmakla birlikte hem devlet hem de toplum seviyesinde bir ilişkiler bütünü öngörmesi hasebiyle sınır-aşan/ulus-ötesi bir mefkûrenin ${ }^{72}$ ifadesi gibi de görünmektedir. Ancak, her ne kadar yazında hayali bir ulus-ötesi nitelikli “Türk dünyası"ndan bahsedilse de bu dünyaya ilişkin çapraz incelemeler neredeyse hiç yoktur. Yani örneğin, Türkiye ile Azerbaycan ya da Kırgızistan arasındaki ilişkiler dış Türkler politikası kapsamında incelenebilirken, Azerbaycan ve Kırgızistan arasındaki ulusal ve/veya ulus-ötesi ilişkilere bu çerçevede bir inceleme getiril(e)memektedir.

67 İlgili politika kapsamında incelenen konuların ve eylemliliklerin genel bir tahlili için bakınız Hüsrev Tabak, The Kosovar Turks and Post-Kemalist Turkey: Foreign Policy, Socialisaiton and Resistance, I.B.Tauris, Londra, 2016.

68 Meşkure Yılmaz, Tarihi Siyasi ve Kültürel Yönleriyle Türklerin Dünyası Türkiye’nin Dış Türkler Politikası, Kripto Yayınları, İstanbul, 2010.

69 Radiye Funda Karadeniz, Türk Dış Politikasında Dış Türkler: Karşılaştırmalı bir Çalışma, Yayınlanmamış Doktora Tezi, Marmara Üniversitesi Sosyal Bilimler Enstitüsü, İstanbul, 2011.

70 Yüksek lisans tezinden makaleleştirilen şu çalışma, konuya ilişkin alternatif bir bakış açısı sunan ve dış Türkler adıyla bir politikanın iç politikayı şekillendirmek için nasıl kullanıldığını ortaya koyan önemli bir incelemedir: Akın Öge, "Türkiye'de Resmî Milliyetçiliğin Türklük Kavrayışı: 'Dış Türkler' odaklı faaliyet gösteren resmî kuruluşların bir incelemesi”, Toplum ve Bilim, Sayı 116, 2009, s.187-214.

71 Örneğin bakınız Ercan Karakoç, Atatürk'ün Dış Türkler Politikası, Yüksek Lisans Tezi, Gebze Yüksek Teknoloji Enstitüsü, Kocaeli, 2001 (Bu çalışma 2002 tarihinde aynı isimle IQ Yayıncılık tarafından kitap olarak basılmıştır); Yeşim Doğan, 1990 Sonrası Türk Dış Politikası'nda Dış Türkler Faktörü, Yayınlanmamış Yüksek Lisans Tezi, Gazi Üniversitesi, Ankara, 2009; Murat Türkmen, Dış Türkler, Yayınlanmamış Yüksek Lisans Tezi, İnönü Üniversitesi, Malatya, 2008.

72 Dış Türkler'in iç politikada ideolojik bir tutum olarak savunusuna ve uluslararası ya da ulus-ötesinin siyasal zihinlerdeki tarihsel inşasına iliş̧in önemli bir çalı̧̧ma için bakınız, Süleyman Tüzün, İkinci Dünya Savaşı Yıllarında Türk İ̧̧ Politikasında Dış Türkler Meselesi (1939-1945), Yayınlanmamış Doktora Tezi, Hacettepe Üniversitesi, Ankara, 1998. Akın Öge'nin çalışması da özellikle 1990'lar sonrasındaki siyasal zihin inşasında dış Türklerin bir kategori olarak oynadığı role ışık tutmaktadır: Öge, "Türkiye'de Resmî Milliyetçiliğin Türklük Kavrayışı". 
Yazının bu nitelikleri göz önüne alındığında, bu yazınca esasen yapılanın farklı coğrafyalarda Türk ismi altında yaşayan bir ulusun varlığına ilişkin somutlaştırıcı bilgi üretimi olduğu görülmektedir. Ayrıca, "dış Türkler politikası” yazını kapsamında milli (daha doğru bir ifadeyle milliyetçi) tarih yazını ve okumasınca üretilmiş kategoriler ve bağlılıklar analiz kategorisi yapılarak onların olumlanmasına katkı sunulmakta, sosyal aktörlerin ulusu ve ulus-devleti doğallaştırma uğraşlarına ortak olunmaktadır. Dahası, Türkiye dâhil, "Türk devletleri” olarak tabir edilen ve tanımlanan ülkelerin tümünde o devletlerde yaşayan toplumların devletler(iy)le özdeşliği öngörülmektedir. Bu noktada, "dış Türkler politikası" yazını hem ulusu hem de ulus-devleti doğallaştırıcı ve somutlaştırıcı bir bilgi üretimi mekanizmasının parçası olmakta, metodolojik ulusçuluğa ilişkin hem ulus-devlet hem de ulusötesi ${ }^{73}$ bağlamda önemli bir yazın örneği teşkil etmektedir.

\section{“Medeniyet” Merkezli Dış Politika Yazımı}

Türkiye'de güncel dönem dış politika yazımında en dikkat çeken metodolojik ulusçuluk pratiği, bu dönemin dış politikasını anlamak için kullanılan, medeniyet merkezli dış politika yazımıdır. Bu pratiğin yaygınlık kazanmasının zemini Ahmet Davutoğlu’nun sosyal bilimci kimliğiyle yazdıklarının sosyal aktör (politikacı) kimliğiyle birlikte popüler hale gelmesinde yatmaktadır. Buna göre, sıklıkla Davutoğlu dönemi dış politikası (ki genel olarak Adalet ve Kalkınma Partisi hükümetlerin tümünü kapsayacak şekilde kullanılıyor) Davutoğlu'nun akademik yazımından hareketle medeniyete referansla açıklanmaktadır. Davutoğlu akademik yazılarında "medeniyet" fikrini Uİ okumasının temeline koymakta, yani onu temel analiz birimi yapmakta ve "dünyayı 'medeniyetlerden müteşekkil bir küre”, dünya tarihini ise, beşerden ziyade "büyüyüp gelişen ve zayıflayan (kimi zaman da ortadan kalkan) bir medeniyetler(in) tarihi olarak” okumaktadır. ${ }^{74}$ Buradan hareketle, Davutoğlu ve medeniyet merkezli okumada, örneğin Türkiye'de dış politika, Türkiye’ye, bölge ülkelerine, “Batılı güçlere” ve Türkiye içerisindeki siyasi/bürokratik bloklara birer medeniyetsel kimlik, aidiyet, ve temsilcilik atfedilerek anlaşılmaya çalışılmaktadır. ${ }^{75}$

İncelemeyi biraz daha derinleştirmek gerekirse; medeniyet Davutoğlu için her zaman insanlararası ilişkileri açıklayıcı bir bağımsız değişken olmuş ${ }^{76}$, bireyin (ve toplumun) medeniyete ilişkin idraki gerek bireysel tahayyül ediş, gerekse devlet aklının tecellisi anlamında dış politikayı şekillendirici bir rol üstlenmiştir. Davutoğlu bu ilişkiyi Türkiye’de dış politika alanına ilişkin olarak şöyle kurmaktadır. Ona göre “Türkiye'deki hakim siyâsi elitin ülkeye biçtiği sistem-içi periferik (ve edilgen) rol Türktoplumunun gerçeklerine, tarihi birikimine ve gelecekle ilgili ideal ve beklentilerine uygun düşmemektedir." Çünkü Türkiye "gerek kadim kültürlerin siyasi tecrübe birikimini gerekse modernleşme sürecinin en temel ve karmaşı unsurlarını barındıran çok yönlü bir tarihi mirasa sahiptir” ve bu miras kendisini

73 Diş Türklerin bir kategori olarak somutlaşmasının ulus-ötesi tarihi niteliği için bakınız Füsun Üstel, "Türk Ocakları ve Dış Türkler”, Semih Vaner (der) Unutkan Tarih - Sovyet sonrası Türkdilli Alan, Metis Yayınları, İstanbul, 1996, s.53-65.

74 Nurullah Ardıç, "Modernite, Kimlik, Siyaset: Ahmet Davutoğlu'nun Medeniyet Söylemi”, Talha Köse vd. (der), Stratejik Zihniyet Kuramdan Eyleme Ahmet Davutoğlu ve Stratejik Derinlik, Küre Yayınları, İstanbul, 2014, s.55.

75 Ibid., s.59. Davutoğlu'nun 'medeniyet'ten ne anladığına ilişkin kavrayışımız net olmakla birlikte, Türkiye'nin bölgesel konumu ve aitliği noktasındaki tavrı beklenmedik şekilde çeşitlilik arz etmektedir. Buna ilişkin bir çalışma için bakınız, Özgür Tüfekçi, “Ahmet Davutoğlu's Foreign Policy Understanding: A Blend of Westernist and Multiculturalist Eurasianism", The Arab World Geographer, Cilt 17, Say1 3, 2014, s.275-289.

76 Ibid., s. 47.

77 Ahmet Davutoğlu, Stratejik Derinlik: Türkiye’nin Uluslararası Konumu, Küre Yayınları, İstanbul, 2001, s.91. 
ülkenin "Doğu ile Batı arasındaki köprü rolü”nü üstlenmesiyle göstermiştir. ${ }^{78}$ Ancak bu köprü rolünün "yeni bir medeniyet açılımına dönüştürüle(bilmesi)" için "Türk toplumu(nun) ... kendi kimliğini, psikolojisini ve siyasi kültürünü yeniden inşa etme(si)” gerekmektedir. ${ }^{79}$ Davutoğlu’na göre, “(b)u psikolojik yenilenmenin dış politika oluşumundaki uzantısı kendi hinterlandını (etki alanı-arka bahçe) tanımlamak olacaktır. Kendisini başkalarının etki alanı olarak görmeye alışmış bir zihniyetin bağımsız bir etki alanı oluşturması mümkün değildir” ${ }^{80}$ Açıkça görülebileceği üzere Ahmet Davutoğlu tarih ve coğrafyayı yeniden yorumlayarak Türk olarak ifade edilen ulusa ve onun devletine dış politikada medeniyetsel bir sorumluluk yüklemekte, devlet ile toplum özdeşliğini milli tarih yazımından farklı bir çerçeveyle ancak geliştirerek olumlamakta, savunmaktadır.

Benzer bir eğilim, özellikle Davutoğlu dönemi olarak anılan sürecin dış politikasını inceleyen çalışmalarda kendini şöylece göstermektedir. Örneğin, Ali Balcı ve Nebi Miş, Türkiye'nin Medeniyetler İttifakı'ndaki rolünü inceledikleri çalışmalarında "AKP yönetiminin Müslüman dünya ile Batı arasındaki mevcut sorunları çözme misyonu(nun), partinin dış politikasındaki -partinin önde gelen isimleri ve Davutoğlu'nun düşüncelerinden hâsıl olan- medeniyetsel tavra ya da boyuta denk gelmekte” olduğunu savunmaktadırlar. ${ }^{81}$ Buna göre Türkiye, Batı ile Müslüman dünya arasındaki sorunların çözümü için önemli bir rol oynamakta, bu rolü gerçekleştirirken de "(h)ükümet üyeleri ve dış politika yapıcıları kendi medeniyetlerinin dışlayıcıdan ziyade kapsayıcı boyutlarına odaklanmaktadırlar". ${ }^{22}$ Yazarlar ayrıca, "Türkiye’nin böyle bir görevi üstlenmek için, stratejik, kültürel ve coğrafi olarak medeniyetlerin kesişim noktasındaki konumundan kaynaklanan önemli bir potansiyeli” olduğunu savunmaktadırlar. ${ }^{83}$

Şaban Kardaş’ın "Davutoğlu ve AKP dış politikasının medeniyet eksenli bir okuması" " olarak atıfta bulunduğu, Burhanettin Duran'ın Türk Dış Politikası Ortadoğululaşıyor mu? başlıklı çalışması (ve takip eden diğer çalışmaları), Davutoğlu dönemine ilişkin medeniyet merkezli ciddi bir tahlil sunarken, metodolojik ulusçuluğa ilişkin de önemli bir örnek teşkil etmektedir. Türkiye’nin Davutoğlu dönemindeki dış politikasını "medeniyet derinliği arayışı” olarak tanımlayan Duran’a göre bu arayış kapsamında "Türk iç ve dış siyasetinde" kimlik/benlik algılamasında ciddi dönüşümler yaşanmış, ülke kendi "medeniyet derinliği” yanı sıra "sadece Osmanlı İmparatorluğu’nun mirası olan bölgelerin değil; yakın kara, deniz ve kıta havzalarının (da) Türkiye'nin stratejik sorumluluğu içinde olduğu(nu)” keşfetmiştir; yani ben-idraki ${ }^{85}$ değişimi yaşamıştır. ${ }^{86} \mathrm{Bu}$ itibarla hükümet dış politikasıyla "Türkiye insanına medeniyet kurma ve düzen oluşturma rolünü hatırlat(ırken)" ${ }^{87}$, yeni medeniyet kimliğiyle de Türkiye'yi medeniyet içi ilişkileri belirleyen (keşfedilen coğrafyalardaki çatışmalar ve sorunların çözümü için standartlar koyan) ve medeniyet dışı ilişkilere taraf (medeniyetler çatışması ve benzeri

78 Ibid., s.93

79 Ibid., s.92

80 Ibid., s.93.

81 Ali Balcı ve Nebi Miş, "Turkey’s Role in the Alliance of Civilizations: A New Perspective in Turkish Foreign Policy?", Turkish Studies, Cilt 9, No.3, 2008, s.388.

82 Ibid., s.388.

83 Ibid., s.388-9.

84 Şaban Kardaş, “Dış Politika'da Eksen Kayması mı?”, Akademik Orta Doğu, Cilt 5, Sayı 2, 2011, s.29, dn. 23.

85 Ahmet Davutoğlu, "Medeniyetlerin Ben-İdraki”, Divan, No.1, 1997, s.3.

86 Burhanettin Duran, “Türk D1ş Politikası Ortadoğululaşıyor mu?”, Ortadoğu Yıllı̆̆ 2008, İstanbul, Küre Yayınlar1, 2009, s.390.

87 Burhanettin Duran, "Türk Diş Politikasın İç Siyaset Boyutu”, Burhanettin Duran, Kemal İnat, Mesut Özcan (der) Türk Dış Politikası Yıllı̆̆ı: 2010 Değerlendirmesi, Seta Yayınları, Ankara, 2011, s.22. 
tartışmalarda etkili bir yere sahip) bir ülke haline getirmiştir. ${ }^{88}$ Duran'ın Türkiye'nin medeniyet derinliği okuması, Davutoğlu'nun büyük medeniyet dönüşümlerinin yaşandı̆̆ı ve "farklı medeniyetlerin birbirleriyle yoğun bir etkileşim halinde oldukları" bir dünyada "bir medeniyet öznesi” ve merkezi bir ülke olarak Türkiye'nin bu sürecin en önemli aktörlerinden biri haline geleceği argümanıyla paralellik göstermekte, onu olumlamaktadır. ${ }^{89}$

Metodolojik ulusçuluk noktasında medeniyet bir analiz birimi ve sosyal kategori olarak, ulus ve ulusdevletin ikamesi durumundadır. Medeniyet merkezli okumada kullanılan Batı, Müslüman dünya, bunlar arasındaki sorun, medeniyetsel tavır ve boyut ifadelerinin tümü metodolojik ulusçulukça eleştirilen "sosyal aktörün ürettiği kategorilerin sosyal bilimci tarafından analiz birimi ve kategorisi olarak kullanılması” eylemine denk gelmektedir. Ancak, sosyal bilimci, bu kez, toplumu ulusla değil de medeniyetle bir tutarken, kendini de ulus-devletinden ziyade öncelikli olarak medeniyetiyle özdeşleştirmektedir; medeniyet-toplum özdeşliği yanı sıra sosyal bilimci-medeniyet özdeşliği kurmaktadır. Beşeri dünyanın örgütlenmesi hususunda da medeniyet perspektifi insanlığı kendini önce devletler sonra medeniyetler olarak örgütlemiş ve medeniyet sınırlarıyla birbirinden ayrılan bir yapı olarak tasavvur etmektedir. Buna göre, topluluklara genelleyici özellikler ithaf edilerek, önce epistemik bir tahayyül olan medeniyet, ardından bu medeniyeti oluşturan kimlikler ve topluluklar doğallaştırılmakta; medeniyet olarak tahayyül edilen gruplar arasındaki "medeniyetsel” seviyedeki ilişkiler dışındaki her türlü iletişim formu analitik olarak yok sayılmakta, görünmez olmaktadır. Doğallaştırılanlar arasında Batı medeniyeti yanı sıra İslam medeniyeti ve bu medeniyetin "bir öznesi olarak” Türk ulus-devleti vardır.

\section{“Türk” Dış Politikası}

Türkiye'de dış politika çalışmalarında en belirgin ve bir o kadar da zımnen yapılan metodolojik ulusçuluk pratiği, dış politika alanı ve sahasının “Türk dış politikası” ismiyle çalışılması ve yazılmasıdır. Bu pratik kendini ders isimleri, ders kitapları, akademik inceleme kitapları, doktora ve yüksek lisans tezleri, bilimsel makaleler ve raporlar ile her alanda göstermekte ve herkes tarafından yapılmaktadır. $\mathrm{Bu}$ anlamda mutlak olarak içselleştirilmiştir.

Peki, bu metodolojik ulusçu pratiğinin anlamı ve sonuçları nelerdir? İlk olarak, "Türk diş politikası"ndaki Türk ifadesi hem devletin hem de ulusun dış politikasını niteliyor ve bunları birleştiriyor. Yani, bu kullanım ulusal toplumu ulus-devletle bir tutuyor ve onları özdeşleştiriyor. Buna göre, adı Türkiye Cumhuriyeti olan bir ulus-devlet ile o devlet ile vatandaşlık bağ bulunan ancak hem bağlılıklar hem de kişi ve grupsal tanımlamalar noktasında kaçınılmaz olarak heterodox, hibrid ve transnasyonel yapılı topluluk arasında ulus ve ulusun devleti ilişkisini kurarken, ulus-devletin eylemlerini ulusa mal ediyor. Söz gelimi ulus-devlet araçları ile yürütülen bir politika alanını ki sıklıkla ifade olunan ülkenin devletler arası diplomatik ilişkileri oluyor, ulus-devlet kabında yaşayan ilgili ulusa/topluma yüklenen bir kişiliğin, kimliğin, iradenin tecellisi olarak yansıtıyor. Ayrıca, buraya ilgili ulus-devlet ile özdeşleştirilen ilgili ulusal toplumun diş politika eliyle Türk olarak tasavvur ve inşa edilmesine katkı sunulduğunu da eklemek gerekir. İkinci olarak bu kullanım dış politikası olan bir Türk ulusundan bahsetmesi hasebiyle dünyanın karşılaştırılabilir ulusal birimlere bölünmüş olduğu anlayışını yansıtırken, insanlığın, kendini ulus-devletler olarak organize etmiş ve diğerlerinden devlet sınırlarıyla ayrılmış, doğal uluslara ayrıldığı varsayımını da desteklemektedir.

88 Duran, “Türk Dış Politikası Ortadoğululaşıyor mu?”, s.387.

89 Ibid., s.391. 
Bu metodolojik ulusçuluk pratiğinin Türkiye'deki alan çalışmalarına has olmadığını ifade etmekte fayda var, çünkü çeşitli devletlerin $d$ ış politikalarının çalışılmasında da sıklıkla benzer bir isimlendirme yönteminin güdüldüğü ortadadır. Örneğin; İtalyan, Rus, Fransız, İngiliz, Alman dış politikaları gibi. Yine Türkiye özelinde dış politika sahasına yabancı dillerde de "Türk dış politikası” isminin verildiğini görüyoruz; Turkish foreign policy, Türkische außenpolitik, La política exterior turca, La politique étrangère turque, Türk xarici siyasəti gibi. Yabancı dillerdeki yayınların yazının gelişiminde önemli bir rolü olduğu düşünüldüğünde bu pratiğin iyice yerleşmiş olması anlaşılır hale gelmektedir. Ayrıca, Türkiye'de dış politika çalışma alanını tanımlamak için “Türk dış politikası” ifadesinin kullanımı 1960’lardan sonra yaygınlaşmıştır, 1990’lar sonrasındaysa hâkim tanımlama ifadesi haline gelmiştir. ${ }^{90} \mathrm{Bu}$ noktada bu çalışma sahasının tarihsel olarak farklı isimleri olduğunu ifade etmekte fayda bulunmaktadır. Örneğin, Ord. Prof. Dr. Yusuf Hikmet Bayur'un 1938 tarihli kitabı Türkiye Devletinin Dış Siyasası ismini taşımaktadır. ${ }^{91} 2000$ 'lere kadar da yayınlar sıklıkla Türkiye'nin Dış Siyaseti, Türkiye Dış Politikası, Türkiye'nin Dış Münasebetleri gibi isimler taşımıştır. ${ }^{92}$ Bu anlamda 2000'lerde "Türk dış politikası” ifadesine alternatif olarak ve daha çok hakim kullanımdaki etnik imayı aşmaya yönelik kullanılan “Türkiye Dış Politikası” ifadesinin ${ }^{93}$ çok da yeni olmadığı görülmektedir. Bu yeni kullanım etnikleştirme pratiği olmama notasında etkili görünse de yazım içeriği metodolojik ulusçuluğun ötesine geçme noktasında bir alternatif sunmamaktadır.

“Türk dış politikası” ifadesinin zımni olarak hâkim kullanım haline gelmesinde ikili ilişkilerin yazımının da etkisi vardır. Buna göre akademik yazında Türk-Arap, Türk-İngiliz, Türk-Fransız, Türk-Sovyet, Türk-Yunan, Türk-Alman, Türk-Ermeni ilişkileri sıkça seçilen çalışma ve inceleme başlıklarındandır. Benzer şekilde ikili anlaşmaların yazımında da aynı yöntem izlenmiş ve örneğin şu anlaşmalar akademik çalışma konusu yapılmıştır; Türk-Sovyet Dostluk ve Saldırmazlık Paktı (1925), Türk-İtalyan Antlaşması (1932), Türk-Alman Saldırmazlık Andlaşması (1941). Benzer bir etkiyi, son olarak, özellikle İstanbul ve Çanakkale boğazlarının uluslararası statülerinin netleştirilmesi konularının yazımında sıklıkla "Türk Boğazları” ifadesine başvuruluyor olması da yapmaktadır.

90 İlk çalışmalara örnek olarak şunlar verilebilir; Mehmet Gönlübol ve Haluk Ülman, "Türk Diş Politikasının 20 Y1lı: 1945-1965”, Ankara Üniversitesi Siyasal Bilgiler Fakültesi Dergisi, Cilt 21, No.1, 1966, s.143-182; Haluk Ülman, "Türk Dış Politikasına Yön Veren Hareketler (1923-1968) I", Ankara Üniversitesi Siyasal Bilgiler Fakültesi Dergisi, Cilt 23, No.3, 1968, s.241-273; Türkkaya Ataöv, "Türk D1ş Politikası Üzerine Düşünceler”, Ankara Üniversitesi Siyasal Bilgiler Fakültesi Dergisi, Cilt 24, No.1, 1969, s.95-121; Haluk Ülman ve Oral Sander, "Türk Dış Politikasına Yöne Veren Hareketler (1923-1968) II”, Ankara Üniversitesi Siyasal Bilgiler Fakültesi Dergisi, Cilt 27, No.1, 1972, s.1-24; Mehmet Gönlübol, “Atatürk Döneminde Türk D1ş Siyasası”, Türk Dili, Cilt 30, No.347, 1980, s.500-503; Oral Sander, "Türk Diş Politikasında Sürekliliğin Nedenleri”, Ankara Üniversitesi Siyasal Bilgiler Fakültesi Dergisi, Cilt 37, No.3-4, 1982, s.105-124; Haluk Gerger, "Türk D1ş Politikası: Bir Genel Çerçeve”, Mülkiyeliler Birliği Dergisi, Cilt 10, No.72-73, 1983, s.31-37.

91 Yusuf Hikmet Bayur, Türkiye Devletinin Dış Siyasası, İstanbul Üniversitesi Yayınları, İstanbul, 1938.

92 Örneğin bakınız, Hamit Batu, “Türkiye'nin Dış Siyaseti”, Dışişleri Belleteni, No.6, Mart 1965, s.21-26; İsmail Soysal, Türkiye’nin Dış Münasebetleriyle İlgili Başlıca Siyasi Andlaşmaları, Ankara, Türkiye İş Bankası Kültür Yayınları, 1965; Edip Çelik, Yüz Soruda Türkiye'nin Dış Politika Tarihi, İstanbul, Gerçek Yayınevi, 1969; Dışişleri Bakanlığı Araştırma ve Siyaset Planlama Genel Müdürlüğü, Türkiye Dış Politikasında 50 Yıl, Ankara, 1973; Seyfi Taşhan, “Türkiye'nin Diş İlişkileri”, Dış Politika, Cilt 10, No.1, 1983; Mehmet Gönlübol, “Atatürk Döneminde Türkiye'nin Dış Politikası”, Milletlerarası Münasebetler Türk Yıllı̆̆ı, 1961, s.197-226.

93 Bakınız Ali Balcı, Türkiye Dış Politikası: İlkeler, Aktörler, Uygulamalar, Etkileşim Yayınları, İstanbul, 2013; Balc1, "Türk” dış politikasındaki Türk ifadesinin "Türk milliyetçisi bir yan anlam dayattığını”, bu sebeple eserinde Türk yerine Türkiye kelimesini kullandığını ifade etmektedir (Kişisel görüşme, 10 Mayıs 2016). 


\section{Sonuç}

Çalışmada, ilk olarak, Uİ ve dış politika çalışmalarında pek üzerinde durulmamış ancak alan üzerinde ciddi kurucu sonuçları olan metodolojik bir problem; metodolojik ulusçuluk ve alanla ilişkisi tanıtılmıştır. Buna göre, metodolojik ulusçuluk, çalışma alanlarının isimlerince sunulan yan anlamlarca da teyit edildiği üzere, Uluslararası İlişkiler ve dış politika çalışmaları için olağan/ beklenen bir pratiktir. Alana verilen isimler iç/dış ve ulusal/uluslararası ikiliklerini güçlendirirken, alanda mevcut çalışma gündemi -ulus-devletlerin beşeri ve uluslar arası dünyayı çalışmak için uygun yapılar oldukları varsayımı ve ulus-devletlerin egemen, birbirinden mutlak olarak ayrışan ve geçirgen olmayan birimler olarak anlaşılması- ulus-devleti ve varsa uluslararası sistemi doğallaştırmaktadır. Buna paralel olarak çalışmada, diğer sosyal bilimler alanlarında olduğu gibi dış politika çalışmalarında da sıkça sosyal aktörün kullanımına metodolojik ulusçu bilgi sunulduğu ve sosyal aktörce üretilmiş kategorilerin analiz birimi olarak kullanılarak, ilgili kategorilerin ve anlatıların somutlaştırılmasına katkıda bulunulduğu savunulmuştur. Makalede ayrıca ulusal sıfatının dış politika çalışmalarında sık kullanılan bir ifade olması hasebiyle topluluklara genelleyici ve ulus-devletle özdeşleştirici özellikler ithaf edildiği iddia edilmektedir.

Bu minvalde ve çalışmanın ikinci amacı çerçevesinde Türkiye'de dış politika çalışmaları örnek incelemesinde yapılan metodolojik ulusçuluk pratikleri ve bunların kurucu etkileri sorgusunda, yazında öngörüldügü üzere mevcut çalışmalarda şu pratiklerin yaygın olduğunu görülmüştür: (i) Sosyal bilimci olarak dış politika çalışan akademisyenler kendi ulus-devletleriyle özdeşlik kurmakta, ülkelerinin ulusal çıkarlarını teyit etmekte ve desteklemekteler. (ii) Sosyal aktörlerce ve milli tarih yazımınca üretilmiş kategoriler, söylemler, bağlllıklar ve tarihler akademisyenlerce analiz kategorisi yapılmakta ve olumlanmakta; sosyal bilimci ile sosyal aktör arasındaki fark (ikincinin lehine) ortadan kalkmaktadır. (iii) Benzer şekilde sosyal aktörlerce üretilmiş ulusal gerçekliklerin (ki bunlar yer yer etnisite, ulus ya da medeniyet olabilir) somutlaşmasına katkı sunulmaktadır. (iv) Toplum, ulusal toplum olarak tahayyül edilerek ve hükümet politikaları ulusa atfedilerek, örneğin dış politika ulusdevlet kabında yaşayan ulusun kişiliğinin, kimliğinin ve iradesinin tecellisi olarak ifade olunarak, devlet ve ulus özdeşleştirilmektedir. (v) Epistemik birer tasavvur olan etnik, ulusal ve medeniyetsel kategoriler doğallaştırılmakta, bu kategoriler dışındaki ilişki formları analitik olarak yok sayılmaktadır. (vi) Dünyanın karşılaştırılabilir ulusal birimlere bölündüğü ve bu ulusal birimler arası ilişkilerin Uİ ve dış politika çalışmalarının merkezi sorgusu olduğu varsayımı desteklenmektedir.

Sonuç olarak, bu metodolojik ulusçu pratikler ile Türkiye'de dış politika çalışan sosyal bilimciler, gözlemledikleri sosyal dünya üzerinde ontolojik ve epistemolojik kurucu etkilere yol açmışlardır. Epistemolojik anlamda dış politika çalışan akademisyenler sosyal aktörlerce üretilmiş ulusal ve medeniyetsel kategorileri analiz birimi yaparak onların somut varlıklar olarak düşünülmelerini olumlamışlardır. Yine, o kategorileri doğallaştırarak sosyal aktörün "Türk ulusu” ve Türk ulus-devleti benzeri ulusal yapıları sürdürmek uğraşları için metodolojik ulusçu "bilimsel” bilgi sunmuşlardır. Bu minvalde ontolojik zemindeyse "Türk ulusu” ve Türk ulus-devleti gibi birimlerin somut varlıklar olarak tahayyül edilmelerine ve "ulusal” ve "uluslararası" gerçeklikler olarak üretilmelerine "bilimsel" katkı sağlamışlardır. 


\section{Kaynakça}

Akşin, Aptülahat. Atatürk'ün Dış Politika İlkeleri ve Diplomasisi, Türk Tarih Kurumu Basımevi, Ankara, 1991.

Amelina, Anna, Devrimsel D. Nergiz, Thomas Faist ve Nina Glick Schiller (der). Beyond Methodological Nationalism: Research Methodologies for Cross-Border Studies, New York, Routledge, 2012.

Ardıç, Nurullah. “Modernite, Kimlik, Siyaset: Ahmet Davutoğlu’nun Medeniyet Söylemi”, Talha Köse vd. (der), Stratejik Zihniyet Kuramdan Eyleme Ahmet Davutoğlu ve Stratejik Derinlik, Küre Yayınları, İstanbul, 2014, s.47-87.

Ataöv, Türkkaya. “Türk Dış Politikası Üzerine Düşünceler”, Ankara Üniversitesi Siyasal Bilgiler Fakültesi Dergisi, Cilt 24, No.1, 1969, s.95-121.

Balcı, Ali. Türkiye Dış Politikası: İlkeler, Aktörler, Uygulamalar, Etkileşim Yayınları, İstanbul, 2013.

Balcı, Ali ve Nebi Miş. “Turkey’s Role in the Alliance of Civilizations: A New Perspective in Turkish Foreign Policy?”, Turkish Studies, Cilt 9, No.3, 2008, s.387-406.

Batu, Hamit. “Türkiye’nin Dış Siyaseti”, Dışişleri Belleteni, No.6, Mart 1965, s.21-26.

Bayur, Yusuf Hikmet. Türkiye Devletinin Dış Siyasası, İstanbul Üniversitesi Yayınları, İstanbul, 1938.

Beck, Ulrich ve Natan Sznaider. “Unpacking Cosmopolitanism for the Social Sciences: a research agenda”, The British Journal of Sociology, Cilt 57, No.1, 2006, s.1-23.

Beck, Ulrich. "Cosmopolitanism as Imagined Communities of Global Risk", American Behavioral Scientist, Cilt 55, No.10, 2011, s.1346-1361.

Beck, Ulrich. "The Cosmopolitan Perspective: Sociology in the Second Age of Modernity”, British Journal of Sociology, Cilt 51, No.1, 2000, s.79-107.

Beck, Ulrich. "The Cosmopolitan Society and its Enemies”, Theory, Culture \& Society, Cilt 19, No.1-2, 2002, s. $17-44$.

Beck, Ulrich. "Toward a New Critical Theory with a Cosmopolitan Intent”, Constellations, Cilt 10, No.4, 2003, s.453-468.

Brubaker, Rogers. Ethnicity Without Groups, Harvard University Press, 2004.

Chernilo, Daniel. "Methodological Nationalism and the Domestic Analogy: Classical Resources for their Critique”, Cambridge Review of International Affairs, Cilt 23, No.1, 2010, s.87-106.

Chernilo, Daniel. “Social Theory's Methodological Nationalism: Myth and Realit”, European Journal of Social Theory, Cilt 9, No.1, 2006, s.5-22.

Chernilo, Daniel. "The Critique of Methodological Nationalism: Theory and History" Thesis Eleven, Cilt 106, No.1, 2011, s.98-117.

Chernilo, Daniel. "Methodological Nationalism and the Domestic Analogy: classical resources for their critique”, Cambridge Review of International Affairs, Cilt 23, No.1, 2010, s.87-106.

Çelik, Edip. Yüz Soruda Türkiye’nin Dış Politika Tarihi, İstanbul, Gerçek Yayınevi, 1969.

Davutoğlu, Ahmet. “Medeniyetlerin Ben-İdraki”, Divan, No.1, 1997, s.1-53.

Davutoğlu, Ahmet. Stratejik Derinlik: Türkiyénin Uluslararası Konumu, Küre Yayınları, İstanbul, 2001.

Dışişleri Bakanlığı Araştırma ve Siyaset Planlama Genel Müdürlüğü, Türkiye Dış Politikasında 50 Yıl, Ankara,1973.

Dilan, Hasan Berke. Atatürk Dönemi Türkiyénin Dış Politikası (1923-1939), Alfa Yayınları, İstanbul, 1998.

Doğan, Yeşim. 1990 sonrası Türk dış politikası́nda dış Türkler faktörü, Yayınlanmamış Yüksek Lisans Tezi, Gazi Üniversitesi, Ankara, 2009. 
Duran, Burhanettin. “Türk Dış Politikası Ortadoğululaşıyor mu?”, Ortadoğu Yıllığı 2008, İstanbul, Küre Yayınları, 2009, s.385-402.

Duran, Burhanettin. “Türk Dış Politikasın İç Siyaset Boyutu”, Burhanettin Duran, Kemal İnat, Mesut Özcan (der). Türk Dış Politikası Yıllığı: 2010 Değerlendirmesi, Seta Yayınları, Ankara, 2011, s.13-64.

Ehata, Rebecca. "Not really 'one of us'? IR, autochthony and the borders of belonging", A paper presented at the 6th Global Conference on Pluralism, Inclusion, and Citizenship, Prague, March 2011.

Gellner, David. "Uncomfortable Antinomies: Going beyond Methodological Nationalism in Social and Cultural Anthropology”, Austrian Academy of Sciences Working Papers in Social Anthropology, Say1 24, 2012, s.1-16.

Gerger, Haluk. “Türk Dış Politikası: Bir Genel Çerçeve”, Mülkiyeliler Birliği Dergisi, Cilt 10, No.72-73, 1983, s.31-37.

Giddens, Anthony. The Nation-State and Violence, Cambridge, Polity Press, 1985.

Gönlübol, Mehmet ve Haluk Ülman. "Türk Dış Politikasının 20 Yılı: 1945-1965”, Ankara Üniversitesi Siyasal Bilgiler Fakültesi Dergisi, Cilt 21, No.1, 1966, s.143-182.

Gönlübol, Mehmet. “Atatürk Döneminde Türk Dış Siyasası”, Türk Dili, Cilt 30, No.347, 1980, s.500-503.

Gönlübol, Mehmet. "Atatürk Döneminde Türkiye’nin Dış Politikası”, Milletlerarası Münasebetler Türk Yıllığı, 1961, s.197-226.

Gönlübol, Mehmet. Atatürk ve Türkiyénin Dış Politikası (1919-1938), Atatürk Araştırma Merkezi Yayınları, Ankara, 1997.

Grande, Edgar. "Cosmopolitan Political Science”, The British Journal of Sociology, Cilt 57, No.1, 2006, s.87-111.

Hellmann, Gunther. “Methodological Transnationalism - Europe’s Offering to Global IR?”, European Review of International Studies, Cilt 1, No.1, 2014, s.25-37.

Irmak, Sadi. “Atatürk’ün Dış Politika İlkeleri”, Atatürk Araştırma Merkezi Dergisi, Cilt 3, No.9, 1987, 487-495.

Karadeniz, Radiye Funda. Türk Dış Politikasında Dış Türkler: Karşılaştırmalı bir Çalı̧ma, Yayınlanmamış Doktora Tezi, Marmara Üniversitesi Sosyal Bilimler Enstitüsü, İstanbul, 2011.

Karakoç, Ercan. Atatürk'ün Dış Türkler Politikası, Yüksek Lisans Tezi, Gebze Yüksek Teknoloji Enstitüsü, Kocaeli, 2001.

Kardaş, Şaban. “Dış Politika'da Eksen Kayması mı?”, Akademik Orta Doğu, Cilt 5, Sayı 2, 2011, s.19-42.

Martins, Herminio. "Time and Theory in Sociology", John Rex (der). Approaches to Sociology, London, Routledge, 1974, s.246-294.

Öge, Akın. “Türkiye’de Resmî Milliyetçiliğin Türklük Kavrayışı: 'Dış Türkler' Odaklı Faaliyet Gösteren Resmî Kuruluşların bir İncelemesi”, Toplum ve Bilim, Sayı 116, 2009, s.187-214.

Robertso, Susan ve Roger Dale. "Researching Education in a Globalising Era: Beyond Methodological Nationalism, Methodological Statism, Methodological Educationism and Spatial Fetishism”, Centre for Globalisation, Education and Societies, University of Bristol.

Robinson, William. "Beyond Nation-State Paradigms: Globalization, Sociology, and the Challenge of Transnational Studies", Sociological Forum, Cilt 13, No.4, 1998, s.561-594.

Sander, Oral. “Türk Dış Politikasında Sürekliliğin Nedenleri”, Ankara Üniversitesi Siyasal Bilgiler Fakültesi Dergisi, Cilt 37, No.3-4, 1982, s.105-124.

Sandıklı, Atilla. Atatürk’ün Dış Politika Stratejisi: Hedefler ve Prensipler, Bilgesam Yay, İstanbul, 2014.

Sarınay, Yusuf. “Atatürk’ten Günümüze Türk Dış Politikası Hakkında Genel Bir Değerlendirme”, Atatürk Araştırma Merkezi Dergisi, Cilt 16, No.48, 2000, s.1-16. 
Schiller, Nina Glick. "Beyond Methodological Ethnicity: Local and Transnational Pathways of Immigrant Incorporation”, Willy Brandt Series of Working Papers in International Migration and Ethnic Relations, Malmö University, 2/08, 2008, s.1-36.

Smith, Anthony D. "Nationalism and Classical Social Theory", British Journal of Sociology, Cilt 34, No.1, 1983, s.19-38.

Soysal, İsmail. Türkiyénin Dış Münasebetleriyle İlgili Başlıca Siyasi Andlaşmaları, Ankara, Türkiye İş Bankası Kültür Yayınları, 1965.

Tabak, Hüsrev. The Kosovar Turks and Post-Kemalist Turkey: Foreign Policy, Socialisaiton and Resistance, I.B.Tauris, Londra, 2016.

Taşhan, Seyfi. “Türkiye’nin Dış İlişkileri”, Dış Politika, Cilt 10, No.1, 1983, s.3-11.

Tüfekçi, Özgür. "Ahmet Davutoğlu’s Foreign Policy Understanding: A Blend of Westernist and Multiculturalist Eurasianism”, The Arab World Geographer, Cilt 17, Sayı 3, 2014, s.275-289.

Türkmen, Murat. Dış Türkler, Yayınlanmamış Yüksek Lisans Tezi, İnönü Üniversitesi, Malatya, 2008.

Tüzün, Süleyman. İkinci Dünya Savaşı yıllarında Türk iç politikasında dış Türkler meselesi (1939-1945), Yayınlanmamış Doktora Tezi, Hacettepe Üniversitesi, Ankara, 1998.

Ülman, Haluk. “Türk Dış Politikasına Yöne Veren Hareketler (1923-1968) I”, Ankara Üniversitesi Siyasal Bilgiler Fakültesi Dergisi, Cilt 23, No.3, 1968, s.241-273.

Ülman, Haluk ve Oral Sander. “Türk Dış Politikasına Yöne Veren Hareketler (1923-1968) II”, Ankara Üniversitesi Siyasal Bilgiler Fakültesi Dergisi, Cilt 27, No.1, 1972, s.1-24.

Üstel, Füsun. “Türk Ocakları ve Dış Türkler”, Semih Vaner (der). Unutkan Tarih - Sovyet sonrası Türkdilli Alan, Metis Yayınları, İstanbul, 1996, s.53-65.

Wimmer, Andreas ve Nina Glick Schiller. "Methodological Nationalism and beyond: Nation-state Building, Migration and the Social Sciences", Global Networks, Cilt 2, No.4, 2002, s.301-334.

Wimmer, Andreas ve Nina Glick Schiller. "Methodological Nationalism, the Social Sciences, and the Study of Migration: An Essay in Historical Epistemology”, International Migration Review, Cilt 37, No.2, 2003, s.576-610.

Wimmer, Andreas. "Herder's Heritage and the Boundary-Making Approach: Studying Ethnicity in Immigrant Societies”, Sociological Theory, Cilt 27, No.3, 2009, s.244-270.

Wolf, Eric. Europe and the People Without History, Berkeley, University of California Press, 1982.

Wolfers, Arnold. Discord and Collaboration: Essays on International Politics, Baltimore, The John Hopkins Press, 1962.

Yalvaç, Faruk. "Devlet”, Atila Eralp (der). Devlet ve Ötesi: Uluslararası İlişkilerde Temel Kavramlar, İstanbul, İletişim Yayınları, 2005.

Yalvaç, Faruk. “Tarihsel Sosyoloji ve Uluslararası İlişkiler: Jeopolitik, Kapitalizm ve Devletler Sistemi”, Uluslararası İlişkiler, Cilt 10, No.38, 2013, s.3-28.

Yılmaz, Meşkure. Tarihi Siyasi ve Kültürel Yönleriyle Türklerin Dünyası Türkiyénin Dış Türkler Politikası, Kripto Yayınları, İstanbul, 2010. 